1 Division of Clinical and Surgical Treatment of Obesity, Faculdade de Medicina do ABC (FMABC), Santo André, SP, Brazil ${ }^{2}$ Sociedade Brasileira de Cirurgia Bariátrica e Metabólica (SBCBM), São Paulo, SP, Brazil

\author{
Correspondence to: \\ Ary Serpa Neto \\ Rua Ossian Terceiro Teles, 220 \\ 04649-000 - São Paulo, SP, Brazi \\ aryserpa@terra.com.br \\ Received on Dec/6/2009 \\ Accepted on Nov/16/2010
}

\section{Relation of uric acid with components of metabolic syndrome before and after RouX-en-Y gastric bypass in morbidly obese subjects}

\author{
Relação do ácido úrico com os componentes da síndrome \\ metabólica antes e após o bypass gástrico com reconstrução \\ em Y-de-Roux em pacientes obesos mórbidos
}

Ary Serpa Neto', Felipe Martin Bianco Rossi', Leonardo Guedes Moreira Valle', Gabriel Kushiyama Teixeira', Marçal Rossi²

\begin{abstract}
Objective: The purpose of the study was to investigate the prevalence of hyperuricemia in morbidly obese subjects before and after Roux-en-Y gastric bypass (RYGBP) and its relationship with metabolic syndrome abnormalities. Subjects and method: We evaluated 420 morbidly obese patients. Pre and postoperative (8 months after RYGBP) blood samples were drawn. Obese patients underwent laparoscopic RYGBP and after eight months all the tests were repeated. Results: The overall prevalence of hyperuricemia was $34.28 \%$. Hyperuricemia was more common in men than in women (51.72 vs. 29.72\%; $p=0.0002)$. Men with hyperuricemia were more likely to have diabetes $(p=0.034)$ and more elevated fasting plasma glucose levels $(p=0.027)$. Women with hyperuricemia were more likely to have hypertension $(p=0.003)$, metabolic syndrome $(p=0.001)$, elevated triglycerides $(p=$ $0.001)$ and GGT $(p=0.009)$, and decreased HDL $(p=0.011)$. After surgery, uric acid levels decreased from $5.60 \pm 1.28$ to $4.23 \pm 1.20(p<0.0001)$. The prevalence of hyperuricemia decreased from $33.6 \%$ to $6.4 \%(p<0.0001)$, in men from $48.3 \%$ to $17.2 \%(p<0.0001)$ and in women from $29.7 \%$ to $3.6 \%$ ( $p<$ 0.0001). Conclusion: Concentrations of uric acid were associated with the prevalence of metabolic abnormalities in this sample of morbidly obese patients. Also, weight loss after RYGBP can reduce uric acid levels and the prevalence of hyperuricemia. Arq Bras Endocrinol Metab. 2011;55(1):38-45
\end{abstract}

Keywords

Uric acid; metabolic syndrome; bariatric surgery

\section{RESUMO}

Objetivo: O objetivo do estudo foi investigar a prevalência de hiperuricemia em pacientes obesos mórbidos antes e após o bypass gástrico com reconstrução em Y-de-Roux (RYGBP) e sua relação com anormalidades da síndrome metabólica. Sujeitos e métodos: Foram avaliados 420 pacientes com obesidade mórbida. Amostras de sangue pré e pós-operatório (8 meses após RYGBP) foram obtidas. Os pacientes obesos foram submetidos a RYGBP laparoscópica e após oito meses todos os testes foram repetidos. Resultados: A prevalência de hiperuricemia foi $34,28 \%$. A hiperuricemia foi mais comum em homens do que em mulheres $(51,72$ vs. $29,72 \%, p=0,0002)$. Homens com hiperuricemia foram mais propensos a ter diabetes $(p=0,034)$ e tinham níveis mais elevados de glicemia de jejum ( $p=0,027)$. Mulheres com hiperuricemia foram mais propensas a ter hipertensão arterial $(p=$ $0,003)$, síndrome metabólica $(p=0,001)$, triglicérides elevado $(p=0,001)$ e GGT $(p=0,009)$ e diminuição de $\mathrm{HDL}(p=0,011)$. Após a cirurgia, os níveis de ácido úrico diminuíram de $5,60 \pm 1,28$ para 4,23 \pm $1,20(p<0,0001)$. A prevalência de hiperuricemia diminuiu 33,6\% para 6,4\% ( $p<0,0001)$, em homens de $48,3 \%$ para $17,2 \%$ ( $p<0,0001)$ e nas mulheres de $29,7 \%$ para $3,6 \%(p<0,0001)$. Conclusão: As concentrações de ácido úrico foram associadas com a prevalência de anormalidades metabólicas nesta amostra de pacientes com obesidade mórbida. Além disso, a perda de peso após RYGBP pode reduzir os níveis de ácido úrico e a prevalência de hiperuricemia. Arq Bras Endocrinol Metab. 2011;55(1):38-45

Descritores

Ácido úrico; síndrome metabólica; cirurgia bariátrica 


\section{INTRODUCTION}

$\mathrm{M}$ etabolic syndrome comprises several abnormalities that occur together more often than would be expected by chance. Typically, general or central adiposity, elevated blood pressure, dyslipidemia, and hyperglycemia are thought to be part of this syndrome. In addition, several other abnormalities including those of fibrinolysis, thrombosis, inflammation, and endothelial function are strongly related to the syndrome.

There continues to be a need to better understand the pattern of risk factor clustering that constitutes metabolic syndrome and the relationship of the syndrome to emerging risk factors for cardiovascular disease. The positive association between serum uric acid and cardiovascular diseases such as stroke or ischemic heart disease has been recognized since the 1950s and has been confirmed by numerous epidemiological studies (1-3). However, whether uric acid is an independent risk factor for cardiovascular mortality is still disputed as several studies have suggested that hyperuricemia is merely associated with cardiovascular diseases because of confounding factors such as obesity, dyslipidemia, hypertension, use of diuretics and insulin resistance $(4,5)$.

Elevated serum uric acid levels (UA) are commonly seen in association with glucose intolerance, hypertension, and dyslipidemia, a cluster of metabolic and hemodynamic disorders which characterize the so-called metabolic syndrome $(6,7)$. Studies performed in healthy volunteers as well as in subjects with asymptomatic hyperuricemia have suggested that the link between metabolic syndrome and serum uric acid is related to the ability of insulin to decrease uric acid clearance in the renal proximal tubule resulting in an increase in serum uric acid levels (8).

The purpose of the present study was to investigate the prevalence of hyperuricemia in morbidly obese subjects before and after Roux-en-Y gastric bypass (RYGBP) and its relationship with metabolic syndrome abnormalities.

\section{SUBJECTS AND METHOD}

\section{Study population}

Four hundred and twenty morbidly obese patients were considered eligible to participate in this study according to the following inclusion criteria: body mass index (BMI) $\geq 40 \mathrm{~kg} / \mathrm{m}^{2}$, age between 18 and 60 years, and no history of liver disease. Most patients (68.5\%) were women and the mean body mass index was $47.1 \pm 5.4 \mathrm{~kg} / \mathrm{m}^{2}$.

\section{Study protocol and follow-up}

Pre and postoperative (at 8 months after bariatric surgery) blood samples were drawn after a minimum fasting period of $8 \mathrm{~h}$. Laboratorial analyses were performed using standard methodologies. BMI is defined as the individual's body weight divided by the square of his/her height. To define metabolic syndrome (MS) we used the International Diabetes Federation (IDF) criteria: waist circumference $\geq 94 \mathrm{~cm}$ in men, $\geq 80 \mathrm{~cm}$ in women or BMI $\geq 30 \mathrm{~kg} / \mathrm{m}^{2}$; triglyceride levels $\geq$ $150 \mathrm{mg} / \mathrm{dL}(1.7 \mathrm{mmol} / \mathrm{L})$ and/or specific treatment; HDL-C levels $<40 \mathrm{mg} / \mathrm{dL}(1 \mathrm{mmol} / \mathrm{L})$ in men, $<50$ $\mathrm{mg} / \mathrm{dL}(1.3 \mathrm{mmol} / \mathrm{L})$ in women and/or specific treatment; fasting glucose $\geq 100 \mathrm{mg} / \mathrm{dL}(5.6 \mathrm{mmol} / \mathrm{L})$ and/or DM2 patient; systolic blood pressure $\geq 130$ $\mathrm{mmHg}$, diastolic blood pressure $\geq 85 \mathrm{mmHg}$ and/or specific treatment. An individual must present at least three of the five risk factors to be diagnosed with MS. Hyperuricemia was defined as uric acid $>6 \mathrm{mg} / \mathrm{dL}$ (women) and $6.8 \mathrm{mg} / \mathrm{dL}$ (men).

The obese patients underwent laparoscopic RYGBP and after eight months all the tests were repeated. RYGBP is a mixed technique that uses more of a restrictive and less of a disabsortive participation. Its main characteristics are the formation of a gastric "pouch" ( $15 \pm 5 \mathrm{~mL}$ ), an alimentary loop of $100 \mathrm{~cm}$, a biliopancreatic loop of $60 \mathrm{~cm}$, and a common loop.

This retrospective study was approved by the Ethics Committee of Faculdade de Medicina do ABC.

\section{Statistical methods}

Data were first tested for normal distribution with the Kolmogorov-Smirnov test. For cross-sectional comparisons, concentration of uric acid between those with and without metabolic syndrome and its components at baseline were compared using ANCOVA adjusted for age and ethnicity. The patients were divided into four equal quarters on the basis of uric acid distributions and linear regression analysis was used to test for trends across the four groups fitting quantitative variables for the four groups.

For prospective analyses baseline means (with SDs) were calculated for subjects in follow-up with $t$ tests, Wilcoxon tests or $\chi^{2}$ tests. The association of uric acid with anthropometric and metabolic variables was evaluated using Pearson correlation analysis controlled for age and ethnicity. Multivariate logistic regression models were used to assess associations of uric acid with 
risk of prevalent metabolic syndrome and with the improvement of it after weight loss, taking in account potential confounders. We evaluated the degree to which uric acid predicted improvement of metabolic syndrome after Roux-en-Y gastric bypass using logistic regression.

All statistical analyses were made with the statistical software package SPSS (vl6.0; SPSS, Chicago, IL) and MedCalc software. Statistical significance was considered at $p<0.05$.

\section{RESULTS}

The overall prevalence of hyperuricemia was $34.28 \%$. Hyperuricemia was more common in men than in women ( 51.72 vs. $29.72 \%$; $\mathrm{p}=0.0002)$. Some characteristics of the study population according to hyperuricemia status are shown in table 1 . Men with hyperuricemia, as compared with those without the condition, were more likely to have diabetes $(\mathrm{p}=0.034)$ and more elevated fasting plasma glucose levels $(\mathrm{p}=0.027)$. Women with hyperuricemia as compared with their counterparts without the condition were more likely to have hypertension $(p=0.003)$, metabolic syndrome $(p=0.001)$, elevated triglycerides $(\mathrm{p}=0.001)$ and GGT $(\mathrm{p}=0.009)$, and decreased HDL ( $\mathrm{p}=0.011)$.

In men, GGT and fasting plasma glucose showed a graded increase according to uric acid quartiles. In women we observed an increase in triglyceride levels and hypertension prevalence (Table 2). In men, mean GGT in the fourth quartile was higher than that in the first quartile $(\mathrm{p}=0.006)$, and in women mean triglycerides in the fourth quartile was higher than that in the first quartile $(\mathrm{p}=0.033)$. The prevalence of metabolic syndrome in men was higher in the second quartile than that in the first quartile $(\mathrm{p}=0.023)$, and the prevalence of hypertension and fasting plasma glucose $\geq 100$ $\mathrm{mg} / \mathrm{dL}$ in the second and fourth quartile was higher than that in the first quartile $(\mathrm{p}=0.002$ for the second quartile and $p=0.009$ for the fourth quartile of hypertension and $\mathrm{p}=0.038$ for the second quartile and $\mathrm{p}=$ 0.009 for the fourth quartile of fasting plasma glucose $\geq$ $100 \mathrm{mg} / \mathrm{dL}$ ). In women the prevalence of hypertension was higher in the third and fourth quartile than that in the first quartile $(\mathrm{p}=0.030$ for the third quartile and $\mathrm{p}=0.000$ for the fourth quartile), and the prevalence of triglycerides $\geq 150 \mathrm{mg} / \mathrm{dL}$ was higher in the fourth quartile than that in the first quartile $(\mathrm{p}=0.000)$.

Pearson's correlation coefficients for the relationship between uric acid and each variable in women were significant for triglycerides $(\mathrm{r}=0.20 ; \mathrm{p}=0.029)$ and GGT $(r=0.23 ; p=0.018)$. In men the correlation was significant also for GGT $(\mathrm{r}=0.45 ; \mathrm{p}=0.013)$ and for fasting plasma glucose $(\mathrm{r}=0.38 ; \mathrm{p}=0.039)$. As shown in table 3 , elevated triglycerides and hypertension were statistically significantly associated with higher uric acid concentration in women. There was no statistical significance between metabolic abnormalities and uric acid concentrations in men.

Table 1. Characteristic of the study population according to hyperuricemia status*

\begin{tabular}{|c|c|c|c|c|c|c|}
\hline \multirow[b]{2}{*}{ Variables } & \multicolumn{3}{|c|}{ Men $(n=87)$} & \multicolumn{3}{|c|}{ Women $(n=333)$} \\
\hline & $\begin{array}{c}\text { Non- } \\
\text { hyperuricemia } \\
(n=42)\end{array}$ & $\begin{array}{l}\text { Hyperuricemia } \\
\quad(n=45)\end{array}$ & $p$ value & $\begin{array}{c}\text { Non- } \\
\text { hyperuricemia } \\
(n=234)\end{array}$ & $\begin{array}{l}\text { Hyperuricemia } \\
\quad(\mathrm{n}=99)\end{array}$ & $p$ value \\
\hline Age (years) & $29.66 \pm 8.3$ & $36.85 \pm 8.8$ & 0.032 & $38.76 \pm 10.1$ & $37.69 \pm 9.7$ & 0.609 \\
\hline $\mathrm{BMI}\left(\mathrm{kg} / \mathrm{m}^{2}\right)$ & $46.49 \pm 4.8$ & $45.06 \pm 5.5$ & 0.469 & $43.73 \pm 4.0$ & $43.79 \pm 4.4$ & 0.945 \\
\hline Hypertension & $15(35.7 \%)$ & $24(53.3 \%)$ & 0.151 & $99(42.3 \%)$ & $60(60.6 \%)$ & 0.003 \\
\hline Diabetes & $3(7.14 \%)$ & $12(26.6 \%)$ & 0.034 & $42(17.9 \%)$ & $15(15.1 \%)$ & 0.644 \\
\hline MS & $22(52.3 \%)$ & $32(71.1 \%)$ & 0.113 & $100(42.2 \%)$ & $63(63.3 \%)$ & 0.000 \\
\hline $\mathrm{TG}(\mathrm{mg} / \mathrm{dL})$ & $217.07 \pm 137.3$ & $181.71 \pm 66.0$ & 0.390 & $130.35 \pm 59.7$ & $179.97 \pm 98.4$ & 0.001 \\
\hline $\mathrm{HDL}(\mathrm{mg} / \mathrm{dL})$ & $45.33 \pm 9.6$ & $44.86 \pm 10.6$ & 0.900 & $49.71 \pm 11.2$ & $43.82 \pm 9.9$ & 0.011 \\
\hline $\mathrm{FPG}(\mathrm{mg} / \mathrm{dL})$ & $92.67 \pm 11.5$ & $111.29 \pm 28.4$ & 0.027 & $96.95 \pm 22.7$ & $101.48 \pm 27.6$ & 0.370 \\
\hline $\mathrm{TB}(\mathrm{mg} / \mathrm{dL})$ & $0.56 \pm 0.1$ & $0.68 \pm 0.4$ & 0.373 & $0.62 \pm 0.6$ & $0.57 \pm 0.2$ & 0.684 \\
\hline $\mathrm{Cr}(\mathrm{mg} / \mathrm{dL})$ & $0.93 \pm 0.1$ & $1.05 \pm 0.2$ & 0.164 & $0.79 \pm 0.1$ & $0.79 \pm 0.1$ & 0.951 \\
\hline GGT (IU/L) & $40.00 \pm 18.9$ & $53.21 \pm 29.1$ & 0.156 & $34.85 \pm 16.3$ & $51.45 \pm 49.7$ & 0.009 \\
\hline
\end{tabular}


Table 2. Baseline characteristics by uric acid quartiles

\begin{tabular}{|c|c|c|c|c|c|}
\hline \multirow{2}{*}{ Variables } & \multicolumn{4}{|c|}{ Quartiles of serum uric acid } & \multirow{2}{*}{$\mathrm{p}$ value } \\
\hline & 1 & 2 & 3 & 4 & \\
\hline \multicolumn{6}{|l|}{ Men (87) } \\
\hline Uric acid range (mg/dL) & $\leq 6.14$ & $6.15-6.69$ & $6.70-7.74$ & $\geq 7.75$ & \\
\hline No. Subjects & 21 & 18 & 27 & 21 & \\
\hline Age (years) & $27.57 \pm 5.6$ & $32.50 \pm 11.7$ & $35.66 \pm 9.0$ & $36.00 \pm 8.8$ & 0.072 \\
\hline $\mathrm{BMI}\left(\mathrm{kg} / \mathrm{m}^{2}\right)$ & $46.26 \pm 4.46$ & $47.89 \pm 6.1$ & $45.80 \pm 6.1$ & $43.53 \pm 3.8$ & 0.260 \\
\hline Uric acid (mg/dL) & $5.22 \pm 0.6$ & $6.45 \pm 0.1$ & $7.07 \pm 0.3$ & $8.11 \pm 0.4$ & 0.000 \\
\hline Total bilirubin (mg/dL) & $0.47 \pm 0.1$ & $0.66 \pm 0.1$ & $0.55 \pm 0.2$ & $0.81 \pm 0.6$ & 0.154 \\
\hline Creatinine $(\mathrm{mg} / \mathrm{dL})$ & $0.88 \pm 0.2$ & $0.91 \pm 0.0$ & $1.08 \pm 0.1$ & $1.04 \pm 0.3$ & 0.108 \\
\hline GGT (IU/L) & $34.14 \pm 19.5$ & $44.66 \pm 19.0$ & $35.77 \pm 19.0$ & $73.71 \pm 22.4$ & 0.003 \\
\hline Triglycerides (mg/dL) & $171.29 \pm 79.1$ & $243.00 \pm 182.6$ & $199.11 \pm 104.6$ & $193.00 \pm 58.2$ & 0.887 \\
\hline $\mathrm{HDL}(\mathrm{mg} / \mathrm{dL})$ & $47.14 \pm 10.1$ & $45.00 \pm 10.5$ & $44.11 \pm 7.8$ & $44.43 \pm 13.3$ & 0.603 \\
\hline Fasting glucose (mg/dL) & $87.00 \pm 5.5$ & $96.83 \pm 14.3$ & $108.11 \pm 28.0$ & $112.14 \pm 27.7$ & 0.027 \\
\hline Metabolic syndrome & $9(42.8 \%)$ & $15(83.3 \%)$ & $12(44.4 \%)$ & $15(71.4 \%)$ & 0.588 \\
\hline Hypertension & $3(14.2 \%)$ & $12(66.6 \%)$ & $12(44.4 \%)$ & $12(57.1 \%)$ & 0.204 \\
\hline $\mathrm{FPG} \geq 100 \mathrm{mg} / \mathrm{dL}$ & $3(14.2 \%)$ & $9(50 \%)$ & $12(44.4 \%)$ & $12(57.1 \%)$ & 0.159 \\
\hline $\mathrm{HDL} \leq 40 \mathrm{mg} / \mathrm{dL}$ & $6(28.5 \%)$ & $6(33.3 \%)$ & $9(33.3 \%)$ & $9(42.8 \%)$ & 0.622 \\
\hline $\mathrm{TG} \geq 150 \mathrm{mg} / \mathrm{dL}$ & $12(57.1 \%)$ & $9(50 \%)$ & $24(88.8 \%)$ & $18(85.7 \%)$ & 0.107 \\
\hline \multicolumn{6}{|l|}{ Women (333) } \\
\hline Uric acid range (mg/dL) & $\leq 4.69$ & $4.70-5.29$ & $5.30-6.09$ & $\geq 6.10$ & \\
\hline No. subjects & 78 & 81 & 81 & 93 & \\
\hline Age (years) & $39.11 \pm 9.1$ & $35.81 \pm 8.8$ & $41.74 \pm 11.7$ & $37.32 \pm 9.6$ & 0.948 \\
\hline $\mathrm{BMI}\left(\mathrm{kg} / \mathrm{m}^{2}\right)$ & $44.82 \pm 5.0$ & $43.32 \pm 3.5$ & $43.11 \pm 3.26$ & $43.78 \pm 4.5$ & 0.346 \\
\hline Uric acid (mg/dL) & $3.77 \pm 0.5$ & $5.02 \pm 0.1$ & $5.62 \pm 0.2$ & $6.56 \pm 0.7$ & 0.000 \\
\hline Total bilirubin (mg/dL) & $0.58 \pm 0.2$ & $0.53 \pm 0.2$ & $0.75 \pm 1.0$ & $0.56 \pm 0.2$ & 0.740 \\
\hline Creatinine (mg/dL) & $0.81 \pm 0.1$ & $0.78 \pm 0.1$ & $0.77 \pm 0.1$ & $0.80 \pm 0.1$ & 0.837 \\
\hline GGT (IU/L) & $36.57 \pm 21.7$ & $34.62 \pm 14.0$ & $45.88 \pm 53.0$ & $41.67 \pm 21.5$ & 0.315 \\
\hline Triglycerides (mg/dL) & $127.23 \pm 62.9$ & $133.19 \pm 63.8$ & $132.30 \pm 52.4$ & $181.61 \pm 101.2$ & 0.008 \\
\hline $\mathrm{HDL}(\mathrm{mg} / \mathrm{dL})$ & $46.85 \pm 10.8$ & $50.67 \pm 10.6$ & $50.15 \pm 12.9$ & $44.61 \pm 9.7$ & 0.366 \\
\hline Fasting glucose (mg/dL) & $94.50 \pm 15.0$ & $103.33 \pm 29.6$ & $96.63 \pm 28.5$ & $98.55 \pm 21.3$ & 0.791 \\
\hline Metabolic syndrome & $42(53.8 \%)$ & $48(52.9 \%)$ & $45(55.5 \%)$ & $42(45.1 \%)$ & 0.607 \\
\hline Hypertension & $27(34.6 \%)$ & $27(33.3 \%)$ & $48(52.9 \%)$ & $57(61.2 \%)$ & 0.003 \\
\hline $\mathrm{FPG} \geq 100 \mathrm{mg} / \mathrm{dL}$ & $21(26.9 \%)$ & $30(37.0 \%)$ & $33(40.7 \%)$ & $30(32.2 \%)$ & 0.757 \\
\hline $\mathrm{HDL} \leq 50 \mathrm{mg} / \mathrm{dL}$ & $51(65.3 \%)$ & $42(51.8 \%)$ & $48(52.9 \%)$ & $69(74.1 \%)$ & 0.281 \\
\hline $\mathrm{TG} \geq 150 \mathrm{mg} / \mathrm{dL}$ & $24(30.7 \%)$ & $33(40.7 \%)$ & $36(44.4 \%)$ & $54(58.0 \%)$ & 0.051 \\
\hline
\end{tabular}

FPG: fasting plasma glucose; TG: triglycerides.

In men, hyperuricemia showed sensitivity and specificity of 41.1 and $50.0 \%$ for the diagnosis of metabolic syndrome and in women sensitivity was $76.2 \%$ and specificity $32.6 \%$ (Figure 1 ).

After surgery, uric acid levels decreased from $5.60 \pm$ 1.28 to $4.23 \pm 1.20(\mathrm{p}<0.0001)$. In men this decrease was from $6.75 \pm 1.12$ to $5.36 \pm 1.42(\mathrm{p}<0.0001)$ and in women from $5.31 \pm 1.14$ to $3.93 \pm 0.93(\mathrm{p}<0.0001)$ (Figure 2). Prevalence of hyperuricemia decreased from
$33.6 \%$ to $6.4 \%(\mathrm{p}<0.0001)$, in men from $48.3 \%$ to $17.2 \%(\mathrm{p}<0.0001)$ and in women from $29.7 \%$ to $3.6 \%$ $(\mathrm{p}<0.0001)$. In women GGT and metabolic syndrome and hypertension prevalence showed a graded increase according to uric acid quartiles (Table 4). In women, mean GGT in the fourth quartile was higher than that in the first and second quartile ( $\mathrm{p}=0.019$ and $\mathrm{p}=0.004$, respectively) and mean triglycerides in the fourth quartile were higher than that in the second quartile $(\mathrm{p}=0.005)$. 
Table 3. Means of uric acid (mg/dL) according to selected features of metabolic abnormalities

\begin{tabular}{|c|c|c|c|c|c|c|}
\hline \multirow{2}{*}{ Variables } & \multicolumn{3}{|c|}{ Men $(n=87)$} & \multicolumn{3}{|c|}{ Women $(n=333)$} \\
\hline & $n$ & Uric acid (mg/dL) & p value & $\mathbf{n}$ & Uric acid (mg/dL) & p value \\
\hline \multicolumn{7}{|l|}{ Metabolic syndrome } \\
\hline Yes & 51 & $6.82 \pm 1.14$ & & 177 & $5.27 \pm 1.14$ & \\
\hline No & 36 & $6.64 \pm 1.14$ & 0.667 & 156 & $5.35 \pm 1.16$ & 0.738 \\
\hline \multicolumn{7}{|l|}{$\mathrm{BMI}$} \\
\hline$<45 \mathrm{~kg} / \mathrm{m}^{2}$ & 51 & $6.91 \pm 1.14$ & & 228 & $5.23 \pm 1.07$ & \\
\hline$\geq 45 \mathrm{~kg} / \mathrm{m}^{2}$ & 36 & $6.52 \pm 1.10$ & 0.372 & 105 & $5.46 \pm 1.29$ & 0.337 \\
\hline \multicolumn{7}{|l|}{ Hypertension } \\
\hline Yes & 39 & $6.96 \pm 1.04$ & & 159 & $5.61 \pm 1.17$ & \\
\hline No & 48 & $6.58 \pm 1.19$ & 0.369 & 174 & $5.03 \pm 1.05$ & 0.007 \\
\hline \multicolumn{7}{|l|}{ Fasting plasma glucose } \\
\hline$<100 \mathrm{mg} / \mathrm{dL}$ & 51 & $6.54 \pm 1.05$ & & 219 & $5.27 \pm 1.20$ & \\
\hline$\geq 100 \mathrm{mg} / \mathrm{dL}$ & 36 & $7.04 \pm 1.20$ & 0.251 & 114 & $5.38 \pm 1.04$ & 0.600 \\
\hline \multicolumn{7}{|l|}{ Triglyceride } \\
\hline$<150 \mathrm{mg} / \mathrm{dL}$ & 24 & $6.22 \pm 1.06$ & & 186 & $5.12 \pm 1.05$ & \\
\hline$\geq 150 \mathrm{mg} / \mathrm{dL}$ & 63 & $6.95 \pm 1.10$ & 0.122 & 147 & $5.54 \pm 1.22$ & 0.044 \\
\hline \multicolumn{7}{|l|}{$\mathrm{HDL}$} \\
\hline$>40 \mathrm{mg} / \mathrm{dL} />50 \mathrm{mg} / \mathrm{dL}$ & 57 & $6.60 \pm 1.12$ & & 123 & $5.16 \pm 0.90$ & \\
\hline$\leq 40 \mathrm{mg} / \mathrm{dL} / \leq 50 \mathrm{mg} / \mathrm{dL}$ & 30 & $7.03 \pm 1.13$ & 0.090 & 210 & $5.39 \pm 1.26$ & 0.277 \\
\hline
\end{tabular}

BMl: body mass index.

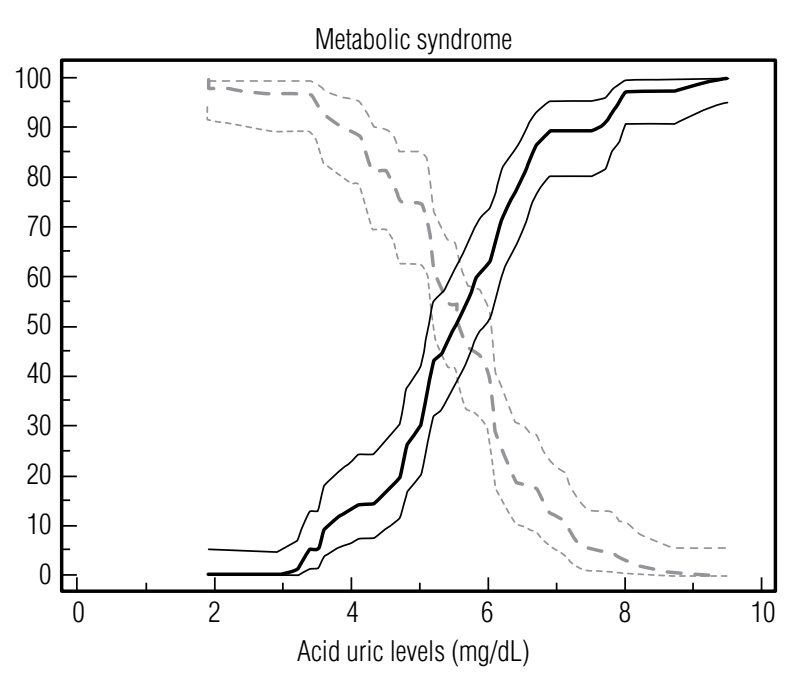

Figure 1. Levels of uric acid for the diagnosis of metabolic syndrome (men and women). Sensitivity (black line) and specificity (gray line).

Patients with improvement of metabolic syndrome after RYGBP showed a greater decrease of uric acid levels than those without improvement of MS (- $1.52 \pm$ 1.10 vs. $1.23 \pm 1.23$, respectively; $\mathrm{p}=0.031)$. In the group of patients with hyperuricemia before RYGBP, those who became normouricemic after surgery showed 2.70 more chance of improvement of metabolic syndrome than those without normalization of uric acid levels.

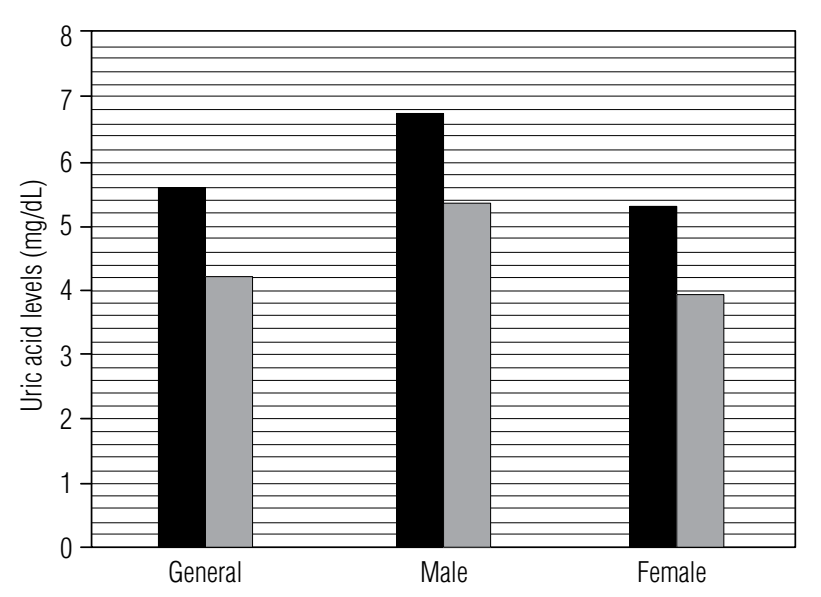

Figure 2. Uric acid levels before (dark bars) and after (gray bars) Rouxen- $Y$ gastric bypass in general, men and women. All $p$ values are less than 0.0001

\section{DISCUSSION}

We showed in the present study that hyperuricemic men have a higher prevalence of diabetes and higher fasting glucose. Women showed a higher prevalence of hypertension, metabolic syndrome, hypertriglyceridemia, and low HDL. In general, elevated levels of uric acid seem to be related to many metabolic abnormalities. Weight loss after RYGBP is accompanied by 
Table 4. Characteristics by uric acid quartiles eight months after RouX-en-Y gastric bypass

\begin{tabular}{|c|c|c|c|c|c|}
\hline \multirow{2}{*}{ Variables } & \multicolumn{4}{|c|}{ Quartiles of serum uric acid } & \multirow{2}{*}{$\mathrm{p}$ value } \\
\hline & 1 & 2 & 3 & 4 & \\
\hline \multicolumn{6}{|l|}{ Men (87) } \\
\hline Uric acid range (mg/dL) & $\leq 4.24$ & $4.25-5.49$ & $5.50-6.24$ & $\geq 6.25$ & \\
\hline No. subjects & 21 & 21 & 24 & 21 & \\
\hline Age (years) & $27.57 \pm 5.9$ & $32.50 \pm 12.7$ & $36.15 \pm 9.1$ & $36.20 \pm 8.9$ & 0.081 \\
\hline $\mathrm{BMI}\left(\mathrm{kg} / \mathrm{m}^{2}\right)$ & $32.96 \pm 5.0$ & $32.89 \pm 3.5$ & $30.78 \pm 3.2$ & $31.66 \pm 4.3$ & 0.367 \\
\hline Uric acid (mg/dL) & $3.62 \pm 0.7$ & $4.70 \pm 0.3$ & $5.91 \pm 0.2$ & $7.15 \pm 0.7$ & $<0.000$ \\
\hline Total bilirubin (mg/dL) & $0.84 \pm 0.3$ & $0.91 \pm 1.0$ & $0.97 \pm 0.7$ & $0.92 \pm 0.4$ & 0.782 \\
\hline Creatinine (mg/dL) & $0.75 \pm 0.1$ & $0.74 \pm 0.1$ & $0.65 \pm 0.0$ & $0.71 \pm 0.1$ & 0.334 \\
\hline GGT (IU/L) & $31.57 \pm 34.1$ & $42.14 \pm 27.0$ & $30.25 \pm 18.1$ & $19.00 \pm 8.2$ & 0.227 \\
\hline Triglycerides (mg/dL) & $96.86 \pm 51.3$ & $92.14 \pm 31.4$ & $86.75 \pm 31.9$ & $99.14 \pm 37.4$ & 0.994 \\
\hline $\mathrm{HDL}(\mathrm{mg} / \mathrm{dL})$ & $33.86 \pm 14.8$ & $44.00 \pm 12.1$ & $40.38 \pm 9.0$ & $42.00 \pm 6.6$ & 0.277 \\
\hline Fasting glucose (mg/dL) & $80.71 \pm 9.3$ & $86.14 \pm 4.1$ & $86.25 \pm 5.7$ & $79.71 \pm 6.2$ & 0.839 \\
\hline Metabolic syndrome & $6(28.5 \%)$ & $3(14.2 \%)$ & $3(12.5 \%)$ & $3(14.2 \%)$ & 0.497 \\
\hline Hypertension & $3(14.2 \%)$ & $3(14.2 \%)$ & $3(12.5 \%)$ & $3(14.2 \%)$ & 0.974 \\
\hline$F P G \geq 100 \mathrm{mg} / \mathrm{dL}$ & $0(0.0 \%)$ & $3(14.2 \%)$ & $0(0.0 \%)$ & $0(0.0 \%)$ & 0.647 \\
\hline $\mathrm{HDL} \leq 40 \mathrm{mg} / \mathrm{dL}$ & $15(71.4 \%)$ & $6(28.5 \%)$ & $15(62.5 \%)$ & $9(42.8 \%)$ & 0.570 \\
\hline $\mathrm{TG} \geq 150 \mathrm{mg} / \mathrm{dL}$ & $3(14.2 \%)$ & $0(0.0 \%)$ & $0(0.0 \%)$ & $3(14.2 \%)$ & 0.983 \\
\hline \multicolumn{6}{|l|}{ Women (333) } \\
\hline Uric acid range (mg/dL) & $\leq 3.29$ & $3.30-3.89$ & $3.90-4.49$ & $\geq 4.50$ & \\
\hline No. subjects & 87 & 78 & 72 & 96 & \\
\hline Age (years) & $39.13 \pm 9.2$ & $34.81 \pm 7.1$ & $41.71 \pm 11.7$ & $38.32 \pm 9.6$ & 0.912 \\
\hline $\mathrm{BMI}\left(\mathrm{kg} / \mathrm{m}^{2}\right)$ & $30.67 \pm 2.8$ & $30.97 \pm 3.2$ & $31.55 \pm 4.8$ & $32.05 \pm 3.5$ & 0.113 \\
\hline Uric acid (mg/dL) & $2.86 \pm 0.4$ & $3.56 \pm 0.1$ & $4.15 \pm 0.1$ & $5.03 \pm 0.6$ & $<0.000$ \\
\hline Total bilirubin (mg/dL) & $0.56 \pm 0.2$ & $0.59 \pm 0.3$ & $0.50 \pm 0.2$ & $0.50 \pm 0.1$ & 0.244 \\
\hline Creatinine (mg/dL) & $0.66 \pm 0.1$ & $0.73 \pm 0.1$ & $0.66 \pm 0.1$ & $0.68 \pm 0.1$ & 0.837 \\
\hline GGT (IU/L) & $17.55 \pm 7.4$ & $15.11 \pm 7.0$ & $21.58 \pm 12.7$ & $28.88 \pm 23.4$ & 0.001 \\
\hline Triglycerides (mg/dL) & $90.66 \pm 28.4$ & $74.00 \pm 23.7$ & $87.75 \pm 28.3$ & $101.56 \pm 37.9$ & 0.067 \\
\hline $\mathrm{HDL}(\mathrm{mg} / \mathrm{dL})$ & $44.86 \pm 11.1$ & $44.54 \pm 9.2$ & $49.08 \pm 15.8$ & $46.84 \pm 11.1$ & 0.323 \\
\hline Fasting glucose (mg/dL) & $82.90 \pm 7.5$ & $81.50 \pm 6.9$ & $81.96 \pm 6.1$ & $85.03 \pm 8.8$ & 0.243 \\
\hline Metabolic syndrome & $3(3.4 \%)$ & $6(7.6 \%)$ & $6(8.3 \%)$ & $18(18.7 \%)$ & 0.043 \\
\hline Hypertension & $0(0.0 \%)$ & $9(11.5 \%)$ & $21(29.1 \%)$ & $21(21.8 \%)$ & 0.006 \\
\hline $\mathrm{FPG} \geq 100 \mathrm{mg} / \mathrm{dL}$ & $3(3.4 \%)$ & $3(3.8 \%)$ & $0(0.0 \%)$ & $6(6.2 \%)$ & 0.705 \\
\hline $\mathrm{HDL} \leq 50 \mathrm{mg} / \mathrm{dL}$ & $63(72.4 \%)$ & $57(73.0 \%)$ & $39(54.1 \%)$ & $72(75 \%)$ & 0.871 \\
\hline $\mathrm{TG} \geq 150 \mathrm{mg} / \mathrm{dL}$ & $3(3.4 \%)$ & $0(0.0 \%)$ & $3(4.1 \%)$ & $9(9.3 \%)$ & 0.191 \\
\hline
\end{tabular}

FPG: fasting plasma glucose; TG: triglycerides.

reduction in uric acid levels and by reduction in the prevalence of hyperuricemia.

Previous studies have showed a close relation between hyperuricemia and metabolic syndrome in adults and children $(9,10)$. Several potential mechanisms could account for the elevated concentrations of uric acid among those with metabolic abnormalities. Renal clearance of urate is inversely related to the degree of insulin resistance (7). Furthermore, higher concentrations of insulin are known to reduce the renal excretion of urate (11). For example, exogenous insulin can reduce renal excretion of urate in both healthy and hypertensive subjects. Thus, the reduced renal excretion of urate among patients with metabolic syndrome may explain the increased frequency of hyperuricemia (12). Insulin may enhance renal urate reabsorption via stimulation of the urate-anion exchanger URATl and/or the $\mathrm{Na}^{+}$-dependent anion cotransporter in brush border membra- 
nes of the renal proximal tubule $(13,14)$. In addition, because serum concentrations of leptin and urate tend to rise together, some investigators have suggested that leptin may affect renal reabsorption $(14,15)$. Increased consumption of fructose, which is associated with obesity, has been shown to elevate concentrations of uric acid $(16,17)$. Finally, in the metabolic syndrome, impaired oxidative phosphorylation may increase systemic adenosine concentrations by increasing the intracellular concentrations of coenzyme A esters of long-chain fatty acids. Increased adenosine, in turn, can result in renal retention of sodium, urate, and water $(18,19)$. Some have speculated that chronically increased extracellular adenosine concentrations may also contribute to hyperuricemia by increasing urate production.

Although hyperuricemia is well recognized as a risk factor for atherosclerotic diseases such as myocardial infarction and stroke, the independence of this association from other confounding factors has remained controversial. This is mostly because serum uric acid is associated with other cardiovascular risk factors, such as hypertension and dyslipidemia (20). Several previous studies have analyzed possible associations between hyperuricemia and coronary heart disease and their independence. Although some studies have reported a positive association between hyperuricemia and coronary heart disease $(21,22)$, others have not $(23,24)$. Most studies showing negative results advocated, as expected, that the association between uric acid and coronary heart disease is not truly independent, but it is dependent on other risk factors for coronary heart disease. On the other hand, it is possible that uric acid is an independent risk factor for coronary heart disease in some selected populations, such as alcohol abstainers (25).

In accordance with previous studies, we found that serum uric acid levels are higher in men than in women, although uric acid levels in women tend to increase above the age of 50 (26). Considering both genders, these differences in serum uric acid levels and the increase after menopause in females have been reported previously and attributed to the influence of sexual hormones (27). We also found that male subjects have a higher prevalence of hyperuricemia than women. The most striking association found in our study is certainly the close relationship between serum triglycerides and serum uric acid levels and hyperuricemia. This observation was made principally in women. The correlation of triglycerides with uric acid has been previously found in several groups of patients $(8,28)$. The mechanism for the strong association of triglyceride values and serum uric acid levels has still not been elucidated. Although, genetic factors have been associated with the concurrence of gout and hypertriglyceridemia, most investigators tend to conclude that hyperuricemia and hypertriglyceridemia reflect more the lifestyle of the patient, as part of the metabolic syndrome, than genetic factors (29).

Sustained weight reduction was accompanied by significant decrease in uricemia as showed by other studies $(30,31)$. Such effect may be explained by a correction of uric acid renal clearance resulting from the near-normalization of hyperinsulinemia and insulin resistance. Besides the already known benefits of bariatric surgery on blood pressure, plasmatic lipids and metabolic syndrome (32-37), improvement of hyperuricemia may contribute to the improvement of cardiometabolic risk in morbidly obese patients.

In conclusion, concentrations of uric acid were associated with the prevalence of metabolic abnormalities in this sample of morbidly obese. Furthermore, weight loss after RYGBP can reduce uric acid levels and the prevalence of hyperuricemia as shown in other articles $(30,38)$.

Disclosure: no potential conflict of interest relevant to this article was reported.

\section{REFERENCES}

1. Gertler MM, Garn SM, Levine SA. Serum uric acid in relation to age and physique in health and coronary heart disease. Ann Intern Med. 1951;54:1421-34.

2. Fang J, Alderman MH. Serum uric acid and cardiovascular mortality. The NHANES I epidemiologic follow-up study, 1971-1992. JAMA. 2000;283:2404-10.

3. Wang JG, Staessen JA, Fagard RH, Birkenhäger WH, Gong L, Liu L; for the Systollic Hypertension in China (Syst-China) Trial Collaborative Group. Hypertension. 2001;37:1069-74.

4. Culleton BF, Larson MG, Kannel WB, Levy D. Serum uric acid and risk for cardiovascular disease and death: The Framingham Heart Study. Ann Intern Med. 1999;131:7-13.

5. De Leeuw PW, Thijs L, Birkenhäger WH, et al. Prognostic significance of renal function in elderly patients with isolated systolic hypertension: results from the Syst-EurTrial. J Am Soc Nephrol. 2002;13:2213-22.

6. Borges RL, Ribeiro AB, Zanella MT, Batista MC. Uric acid as a factor in the metabolic syndrome. Curr Hypertens Rep. 2010;12:113-9.

7. Facchini F, Ida Chen Y-D, Hollenbeck CB, Reaven GM. Relationship between resistance to insulin-mediated glucose uptake, urinary uric acid clearance and plasma uric acid concentration. JAMA. 1991;266:3008-11.

8. Rathmann W, Funkhouser E, Dyer AR, Roseman JM. Relations of hyperuricemia with the various components of the insulin resistance syndrome in young black and white adults: the CARDIA 
study. Coronary Artery Risk Development in Young Adults. Annals Epidemiol. 1998;8:250-61.

9. Ford ES, Li C, Cook S, Choi HK. Serum concentrations of uric acid and the metabolic syndrome among US children and adolescents. Circulation. 2007;115:2526-32.

10. Ishizaka N, Ishizaka $Y$, Toda $E$, Nagai $R$, Yamakado M. Association between serum uric acid, metabolic syndrome, and carotid atherosclerosis in Japanese individuals. Arterioscler Thromb Vasc Biol. 2005;25:1038-44.

11. Ter Maaten JC, Voorburg A, Heine RJ, Ter Wee PM, Donker AJ, Gans RO. Renal handling of urate and sodium during acute physiological hyperinsulinaemia in healthy subjects. Clin Sci (Lond). 1997;92:51-8.

12. Muscelli E, Natali A, Bianchi S, Bigazzi R, Galvan AQ, Sironi AM, et al. Effect of insulin on renal sodium and uric acid handling in essential hypertension. Am J Hypertens. 1996;9:746-52.

13. Enomoto A, Kimura $H$, Chairoungdua A, et al. Molecular identification of a renal urate anion exchanger that regulates blood urate levels. Nature. 2002;417:447-52.

14. Choi HK, Mount DB, Reginato AM. Pathogenesis of gout. Ann Intern Med. 2005;143:499-516.

15. Lin JD, Chiou WK, Chang HY, Liu FH, Weng HF. Serum uric acid and leptin levels in metabolic syndrome: a quandary over the role of uric acid. Metabolism. 2007;56:751-6.

16. Ludwig DS, Peterson KE, Gortmaker SL. Relation between consumption of sugar-sweetened drinks and childhood obesity: a prospective, observational analysis. Lancet. 2001;357:505-8.

17. Heinig $M$, Johnson RJ. Role of uric acid in hypertension, renal disease, and metabolic syndrome. Cleve Clin J Med. 2006;73:1059-64.

18. Dhalla AK, Wong MY, Voshol PJ, Belardinelli L, Reaven GM. A1 adenosine receptor partial agonist lowers plasma FFA and improves insulin resistance induced by high-fat diet in rodents. Am J Physiol Endocrinol Metab. 2007;292:E1358-63.

19. Castrop H. Mediators of tubuloglomerular feedback regulation of glomerular filtration: ATP and adenosine. Acta Physiol (Oxf). 2007;189:3-14

20. Nagahama K, Iseki $K$, Inoue T, Touma T, Ikemiya $Y$, Takishita S. Hyperuricemia and cardiovascular risk factor clustering in a screened cohort in Okinawa, Japan. Hypertens Res. 2004;27:227-33.

21. Tangri N, Weiner DE. Uric Acid, CKD, and cardiovascular disease: confounders, culprits, and circles. Am J Kidney Dis. 2010;56:247-50.

22. Palmer IM, Schutte AE, Huisman HW. Uric acid and the cardiovascular profile of African and Caucasian men. J Hum Hypertens. 2010;24(10):639-45. Epub 2010 Feb 11.

23. Zoppini G, Targher G, Negri C, Stoico V, Perrone F, Muggeo M, et al. Elevated serum uric acid concentrations independently predict cardiovascular mortality in type 2 diabetic patients. Diabetes Care. 2009;32:1716-20.
24. Santos RD. Uric acid and cardiovascular disease: how to solve another chicken or egg puzzle. Cardiology. 2009;114:298-9.

25. Iribarren C, Sharp DS, Curb JD, Yano K. High uric acid: a metabolic marker of coronary heart disease among alcohol abstainers. J Clin Epidemiol. 1996;49:673-8.

26. Freedman DS, Williamson DF, Gunter EW, Byers T. Relation of serum uric acid to mortality and ischemic heart disease. The NHANES I epidemiologic follow-up study. Am J Epidemiol. 1995; 141:637-44.

27. Gordon T, Kannel WB. Drinking and its relation to smoking, blood pressure, blood lipids, and uric acid. The Framingham Study. Arch Int Med. 1983;143:1366-74.

28. Conen D, Wietlisbach V, Bovet P, Shamlaye C, Riesen W, Paccaud $F$, et al. Prevalence of hyperuricemia and relation of serum uric acid with cardiovascular risk factors in a developing country. BMC Public Health. 2004;4:9.

29. MoriwakiY, Tetsuya Y, Takahashi S, Tsutsumi Z, Higashino K. Apolipoprotein $E$ phenotypes in patients with gout: relation with hypertriglyceridemia. Ann Rheum Dis. 1995;54:351-4.

30. Sjöström L, Lindroos AK, Peltonen M, Torgerson J, Bouchard C, Carlsson B, et al. Lifestyle, diabetes, and cardiovascular risk factors 10 years after bariatric surgery. N Engl J Med. 2004;351:2683-93.

31. Luyckx FH, Scheen AJ, Desaive C, Dewe W, Gielen JE, Lefebvre PJ. Effects of gastroplasty on body weight and related biological abnormalities in morbid obesity. Diabetes Metab. 1998;24:355-61.

32. Serpa Neto A, Rossi FM, Amarante RD, Buriti NA, Rossi M. Impact of plasmatic lipids in glycemic control and its influence in the cardiometabolic risk in morbidly obese subjects. Arq Bras Endocrinol Metabol. 2009;53:747-54.

33. Serpa Neto A, Bianco Rossi FM, Dal Moro Amarante R, Alves Buriti N, Cunha Barbosa Saheb G, Rossi M. Effect of weight loss after Roux-en-Y gastric bypass, on renal function and blood pressure in morbidly obese patients. J Nephrol. 2009;22:637-46.

34. Rossi M, Barretto Fereira da Silva R, Chaves Alcântara G Jr, Regina PF, Martin Bianco Rossi F, et al. Remission of metabolic syndrome: a study of 140 patients six months after Roux-en-Y gastric bypass. Obes Surg. 2008;18:601-6.

35. Novais PF, Rasera Junior I, Leite CV, Oliveira MR. Body weight evolution and classification of body weight in relation to the results of bariatric surgery: roux-en-Y gastric bypass. Arq Bras Endocrinol Metabol. 2010;54:303-10.

36. Carvalho PS, Moreira CL, Barelli Mda C, Oliveira FH, Guzzo MF, Miguel GP, et al. Can bariatric surgery cure metabolic syndrome? Arq Bras Endocrinol Metabol. 2007;51:79-85.

37. Geloneze B, Pareja JC. Does bariatric surgery cure the metabolic syndrome? Arq Bras Endocrinol Metabol. 2006;50:400-7.

38. Nakanishi N, Nakamura K, Suzuki K, Matsuo Y, Tatara K. Relation of body weight change to changes in atherogenic traits: a study of middle-aged Japanese obese male office workers. Ind Health. 2000;38:233-8. 